AJIE - Asian Journal of Innovation and Entrepreneurship

(e-ISSN: 2477- 0574; p-ISSN: 2477-3824)

Vol. 02, No. 01, January 2017

\title{
EXPORT PERFORMANCE IMPROVEMENT THROUGH MANAGEMENT AND TECHNOLOGY SUPPORT FOR SMES CRAFT
}

\author{
Nugroho Mardi Wibowo', Yuyun Widiastuti², Siswadi ${ }^{3}$ \\ ${ }^{1}$ Management, Wijaya Putra University, Surabaya, Indonesia \\ ${ }^{2}$ Management, Wijaya Putra University, Surabaya, Indonesia \\ ${ }^{3}$ Mechanical Engineering, Wijaya Putra University, Surabaya, Indonesia \\ *Corresponding E-mail : nugrohomardi@uwp.ac.id
}

\begin{abstract}
Specific targets of this activity are: (i) SMEs can increase turnover; (ii) SMEs can enhance variety of design products; (iii) SMEs have skilled human resources on product design; (iv) SMEs can prepare financial statements; (v) SMEs have a standard quality assurance; (vi) SMEs can improve product quality and speed up the production process; (vii) Obtaining copyrights products. Methods of implementation of this program include: training and assistance with activities such as: the manufacture of machinery and production equipment, supply of equipment, participation in exhibitions, arrangement of storage space and show room, cooperating with other parties as well as the processing of copyright products. The results obtained from these activities, first with the brass foundry furnace and molds made of firebrick resulted in increased speed of production processes as well as fuel efficiency and cost of production for SME-1 "Whisnu". It took only three hours to the cooking process cast brass with a capacity of $120 \mathrm{~kg}$ previously take longer that 5 hours. Secondly, Machine Mixer Fiber Materials for Partners "Java Fiber" can shorten the process of mixing the fiber material to be faster, employees are not tired and product quality is getting better and there is no defective products. Fiber material mixing machine can stir $25 \mathrm{~kg}$ fiber material for 5 minutes, while the previous manual way takes 1 hour to stir $25 \mathrm{~kg}$ fiber. Thirdly, it has been conducted Partners Products Exhibition. Fourth, it generates three new product design by SME-1 "Whisnu" and 4 design new products by SME-2 "Java Fiber". Fifth, the proposed copyright has begun to partner products to the Ministry of Justice and Human Rights. This activity resulted in increased revenue of SMEs $10 \%$ per year.
\end{abstract}

Keywords: Craft, SME, Export, Jombang

\begin{abstract}
ABSTRAK
Target spesifik dari kegiatan ini adalah: (i) UKM dapat meningkatkan omset; (Ii) UKM dapat meningkatkan berbagai produk desain; (Iii) UKM memiliki sumber daya manusia yang terampil pada desain produk; (Iv) UKM dapat menyusun laporan keuangan; (V) UKM memiliki jaminan kualitas standar; (Vi) UKM dapat meningkatkan kualitas produk dan mempercepat proses produksi; (Vii) Memperoleh produk hak cipta. Metode pelaksanaan program ini meliputi: pelatihan dan bantuan dengan kegiatan seperti: pembuatan mesin dan peralatan produksi, penyediaan peralatan, partisipasi dalam pameran, penataan ruang penyimpanan dan show room, bekerja sama dengan pihak lain serta pengolahan produk hak cipta. Hasil yang diperoleh dari kegiatan ini, pertama
\end{abstract}


dengan kuningan pengecoran tungku dan cetakan yang terbuat dari batu bata tahan api mengakibatkan peningkatan kecepatan proses produksi serta efisiensi bahan bakar dan biaya produksi untuk UKM-1 "Whisnu". Ini hanya membutuhkan waktu tiga jam untuk proses memasak cor kuningan dengan kapasitas $120 \mathrm{~kg}$ sebelumnya memakan waktu lebih lama yang 5 jam. Kedua, Mesin Mixer Fiber Bahan untuk Mitra "Java Fiber" dapat mempersingkat proses pencampuran bahan serat menjadi lebih cepat, karyawan tidak lelah dan kualitas produk semakin baik dan tidak ada produk yang cacat. bahan serat mesin pencampuran dapat menggerakkan $25 \mathrm{~kg}$ bahan serat selama 5 menit, sedangkan cara manual sebelumnya membutuhkan waktu 1 jam untuk menggerakkan 25 serat kg. Ketiga, telah dilakukan Pameran Mitra Produk. Keempat, itu menghasilkan tiga desain produk baru dengan UKM-1 "Whisnu" dan 4 desain produk baru dengan UKM-2 "Java Fiber". Kelima, hak cipta yang diajukan sudah mulai produk mitra untuk Departemen Kehakiman dan Hak Asasi Manusia. Kegiatan ini menghasilkan peningkatan pendapatan dari UKM 10\% per tahun.

Kata kunci: Craft, UKM, Ekspor, Jombang

\subsection{Introduction}

The role of the sector of Small and Medium Enterprises (SMEs) in the economy is very important in Indonesia because it can create markets, expand trade, manage natural resources, reduce poverty, create jobs, build communities and support their families. The existence and development of SMEs without controls and adequate fasiltias from the government [1].

The existence of SMEs is no doubt because it proved able to survive and become the economic driving, especially after the economic crisis. On the other hand, SMEs are also facing many problems, the limited working capital, human resources is low, and less cakapnya mastery of science and technology [2]. Another obstacle faced by SMEs is the relationship with the business outlook is less clear and the vision and mission planning is not yet stable.

SMEs maker souvenir products made of cast brass or fiber, is a prospective industries. SME products souvenir industry has high artistic value so popular with consumers, not only the domestic market but also the international market. SMEs.
SMEs souvenir industry's partner community service activities (PPM) are SME "Whisnu" and SME "Java Fiber". SME "Whisnu" is located at Sanan Selatan I No. 18 South I Mojotrisno, Rural District of Mojoagung Kabupaten Jombang with the owner Mr. Sukirno. SMEs "Whisnu" produce souvenirs made from cast brass in the form of a statue. SMEs "Java Fiber" is located at Jl. Perak 1 Banjardowo, Jombang with the owner Mr. Roni Apriyanto. SME "Java Fiber" produce souvenirs made from raw fiber in the form of statues, souvenir for wedding, birthday, ornaments, etc.

Same with SMEs in general, SMEs Whisnu and Java Fiber can not be separated from pemasalahan. Both partners experienced some problems PPM activities covering aspects of production, processes, products, management, marketing, human resources (HR) and financial facilities. Manufacturing SME "Whisnu" faces problems including a brass cooking process takes a long time. This is due to raw material furnace used red bricks, not fireproof. Meanwhile SME "Java Fiber" encountered problems surface in a small 
hollow products for the mixing process is less than perfect fiber that has been stirring is done manually.

In the aspect of the product, both partners have similar problems. The product design both partners are imitating other products and based on the examples provided by the buyer. Product standardization both partners are still missing.

Problems in management, both partners face the same thing. Both are yet to implement financial management and accounting is correct in recording expenditure and inclusion of companies. Issues management is yet another processing Products Copyright whereas the product lots of potentially getting Products Copyright.

Export sales through the broker so that the export market is still limited. It is the marketing problems faced by both partners. Participation in the exhibition has been carried out by SMEs "Java Fiber" both nationally and internationally, while SMEs ", while the participation of SMEs" Whisnu "in the cast is still very limited.

In the field of human resources, both partners have the same problems that do not already have competent human resources in terms of product design, in addition to the owner.

Amenities of the showroom both partners are still not well ordered. Likewise, storage of raw materials is still seen not tidy

On the financial aspect, the condition of both the partners are similar. Both have limited working capital.

The main objective of this activity is spurring the growth of Community Services (PPM) products export partner souvenir. Second, accelerate the transfer of technology and management from the University of Wijaya Putra as the implementing PPM partners. The special target of this activity are: (i) SMEs can increase turnover; (ii) can increase the variety of product design; (iii) SMEs have skilled human resources on product design; (iv) SMEs can prepare financial statements; (v) SMEs have a standard of quality assurance; (vi) improve product quality and speed up the production process; (vii) obtaining copyright products.

\subsection{Source of Inspiration}

Some of the problems faced by quite diverse partners. Brass cooking process takes a long time. Production and finishing equipment is limited. Product is still not perfect and less smooth surface. Total production of timely and quality is not maximized. Pengadministrasi financial partner still does not meet the minimum standards of accounting. Partner products have high artistic value, but the filing of copyright has never been done. Participation in the exhibition is still limited. human resources field, yet have skilled human resources for product design. Showroom is still not well ordered.

\subsection{Methodology}

PPM implementation is using several methods in an attempt to resolve the problems faced by the partners. The methods used in the implementation of PPM are as follows:

1) Science and technology Substitution In this PPM activities, for SMEs "Whisnu" made, cast brass cooking stove made of refractory bricks that were previously only ordinary red brick. While SMEs "Java Fiber" will be created machine agitator (mixer) fiber which previously by hand, stir the fiber material by hand. 
2) Training

The training was conducted to train partners to be able to operate and maintain the equipment / science and technology that has been given to partners as well as aspects of management that should be known by the partner.

3) Consultation and Assistance

Mentoring is done every two weeks or depending on the need to resolve the problems facing our partners in both technology and management issues. In the process of mentoring course of interaction and consultation between the partners and implementing PPM in order to resolve the problems faced by the partners.

\subsection{Results and Discussions}

Making Furnaces Cast Brass with Refractory Bricks made to accelerate the process of casting material into a liquid brass to brass which is inserted into the mold products requested in accordance with consumer demand. Brass casting process using a new furnace made of refractory bricks requires a shorter time compared to the old furnace, which is 3 hours for a capacity of $120 \mathrm{~kg}$ brass. While the old foundry furnace takes 5 hours for brass same capacity.

Besides held renovation cooking stove foundry brass, there is also a burning furnace repair mold products. The walls of the furnace mold products are replaced with firebrick. With the replacement of the furnace wall molding products with firebrick impact on the combustion process becomes faster mold which is 1.5 hours before 2.5 hours. You may insert results and discussions note.
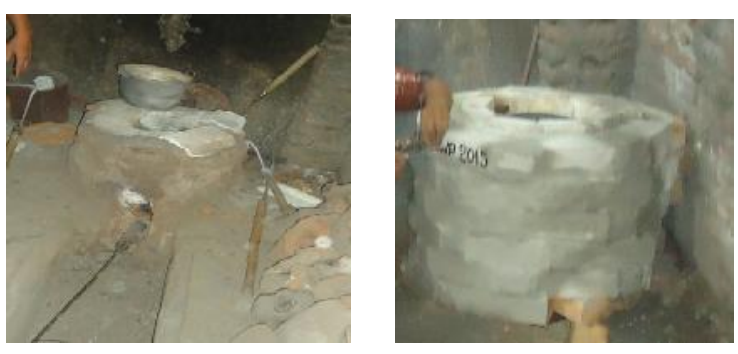

Figure 1. Furnace of Brass Foundry. The Furnace old (left) and the new furnace (right)

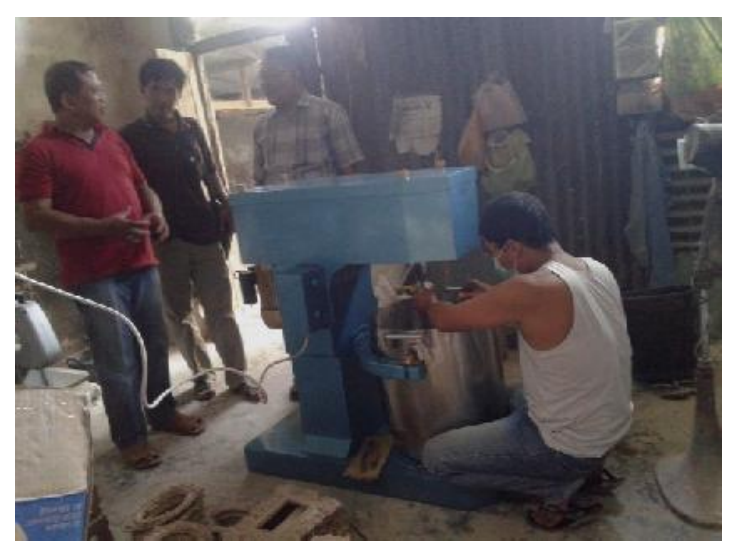

Figure 2. Training Operation and Maintenance Fiber Materials Mixer Machine

Based on the results of monitoring the production process that shows no defective products for fiber mixing process is not perfect so that no parts are uneven or textured fibernya hollow. During this mixing process the fiber material is done by means of fiber material menual or stirring by hand. The stirring process the fiber material by hand cause the product is less than perfect, uneven, hollow fiber texture, and manpower quickly exhausted for stirring and mixing process takes a long time. As a solution to these problems made machine agitator (mixer) fiber. With fiber material mixing machine is expected to work stirring fiber materials can be faster. Besides, the process of mixing the ingredients so that the fiber can be more perfect souvenir products no holes or hollow, and workers do not feel tired. Fiber material mixing machine (mixer) could stir 
$25 \mathrm{~kg}$ fiber material for 5 minutes, while the previous manual way takes 1 hour for stirring $25 \mathrm{~kg}$ of fiber.

Showroom owned by partner 1 "Whisnu" looks not kept clean so impressed looks less beautiful when the goods are stored has a high artistic value. While the show room products partner 2 "Java Fiber" is still fused with administrative space and space pimpiman. The arrangement of items on show room look still neat. In connection with that, so that both partners showroom look neat and beautiful then the need for restructuring. Showroom on partner 1 "Whisnu" has been held structuring on cabinets storefronts and long tables. While the show room on two partners "Java Fiber" has made cabinets / racks display products that have been produced. In the two partners "Java Fiber", a show room that was developed not at the place of production (factories) but home owners is Perumahan Pondok Indah Jombang. By structuring the showroom, that both partners show room look neat and beautiful.
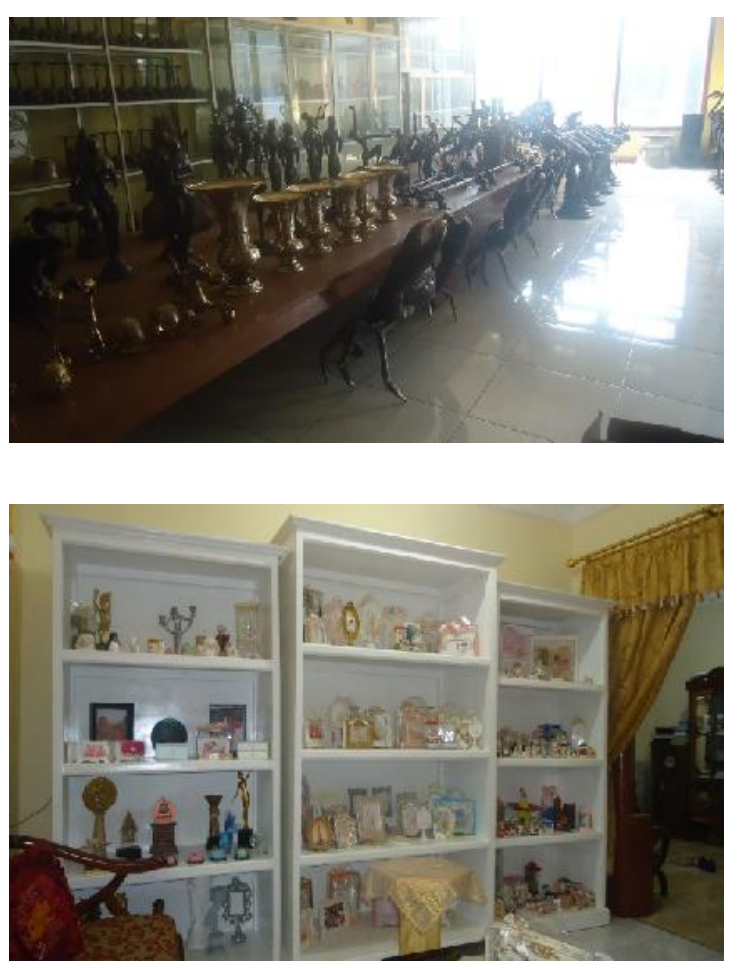

Figure 3. Showroom SME "Whisnu" (top) and SME "Java Fiber" (below)

Intellectual Property Rights (IPR) Java Fiber products are in IPR's still no. Based on interviews with the owners of Java Fiber Mr. Ronni Apriyanto said that in fact there is potential products in late-IPR, but variations of the product is very much that the registration of patents can not be done. Java Fiber get potential product IPRs big enough because it has high artistic value. For Intellectual Property Rights (IPR) products "Whisnu" which in IPR's still no. Products "Whisnu" potentially IPR because production has high artistic value. Based on these problems, it is necessary to the maintenance of intellectual property rights for products of good partners "Whisnu" or "Java Fiber". In early June 2015 we filed each 1 (one) product partners to get the Copyright of the Ministry of Justice and Human Rights by the Chairman of Hang Tuah University Intellectual Property Center. The list of partner products which filed the copyright to the Ministry of Justice and Human Rights is the "Horse Antique" belongs SME "Whisnu" and "The Toothpick Koala" belongs SME "Java Fiber".

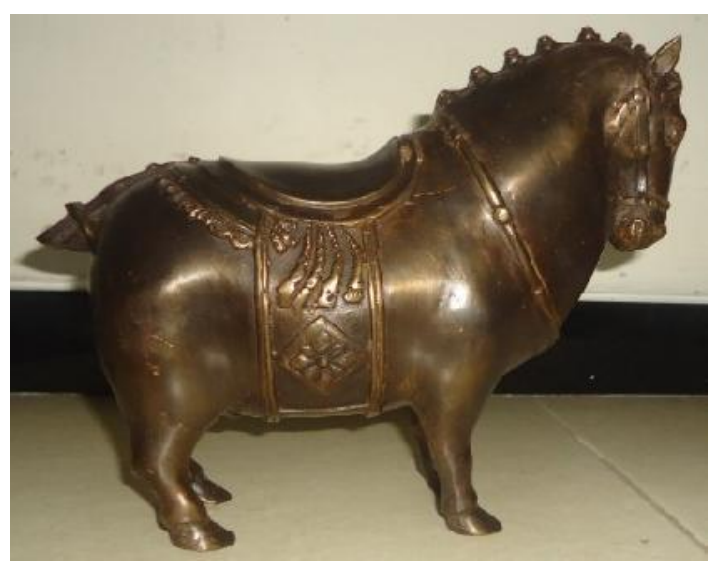




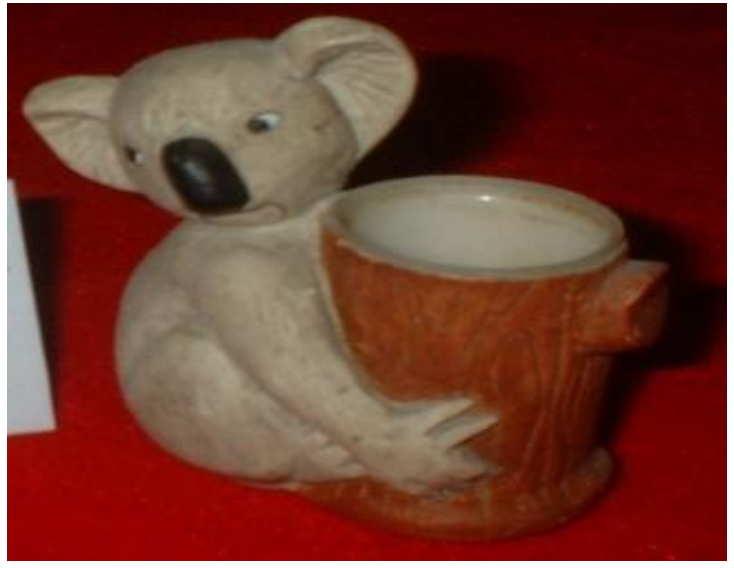

Figure 4. Products "Antique Horse" (above) belonging to SME "Vishnu" and Toothpick Koala (bottom) of SME "Java Fiber"

In order to expand its market coverage, Java Fiber always follow the cast handicraft products both at district, provincial, national or international. Some actors both local, national and international have been followed by Java Fiber include: Exhibition Potential Craft Products in East Java, "The 14th Jakarta International Handicraft Trade Fair (Inacraft)", SMESCO Jakarta, Rich Expo Jakarta, the Jakarta Fair, and Banjabaru Fair. Besides, Java Fiber following the trade mission in East Java province on Trade Acceleration program Inter-island province of East Java and Bangka Belitung. Another marketing technique is working with the Government, namely Java Jombang Fiber sells its products at the Show "Pusat Oleh-Oleh" Jombang. In 2015 these two partners "Java Fiber" follows the exhibition "The potential Gebyar Jombang" held in Jombang on July 25 until July 30, 2015 August 2, 2015. After Partner "Java Fiber" also follows the exhibition "NU Expo and Bazaar People "in Jombang June 1 to August 5, 2016.

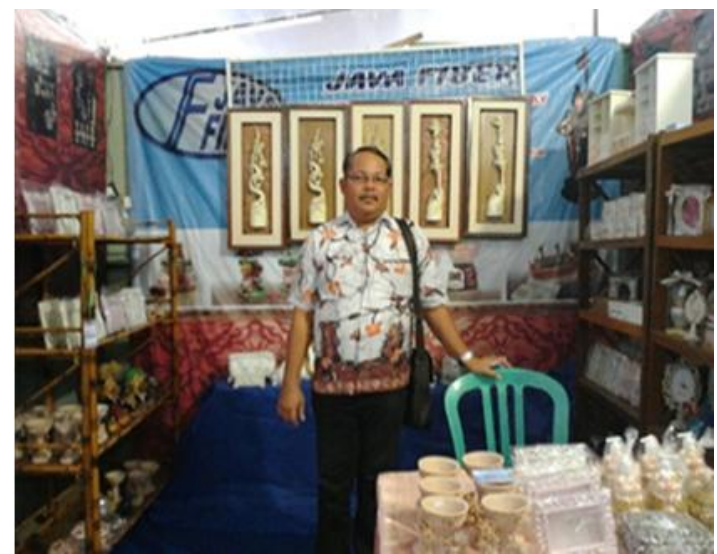

Figure 5. The exhibition, followed by SMEs "Java Fiber"

The addition of the new product design is done in order to meet customer demand. Souvenir industry is required to develop products on an ongoing basis based on the customer favors. Based on the facilitation of the development of new product design by Tim IbPE UWP to the partners that SMEs "Whisnu" SME "Java Fiber", partners can develop new. Some of the products that have been developed by partners including "mask sculpture" by SME partners "Java Fiber" and "Crab Giant" by SMEs "Whisnu".

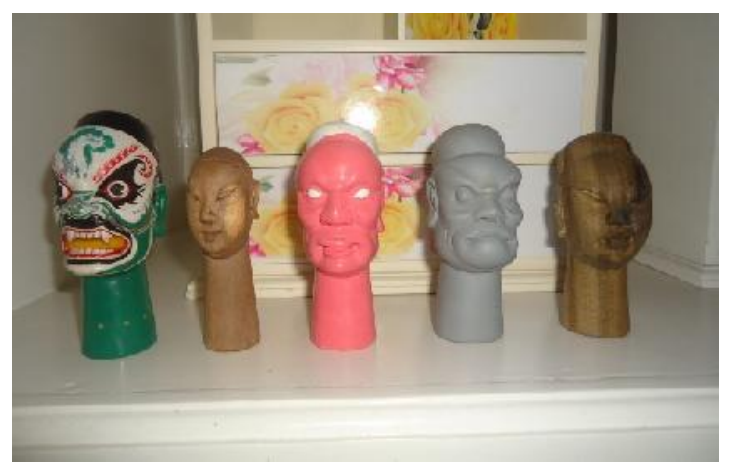

Figure 6. New Products SME “Java Fiber”

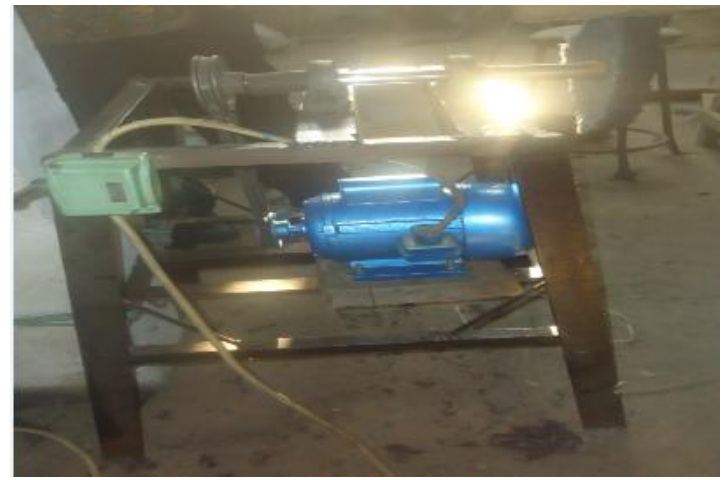




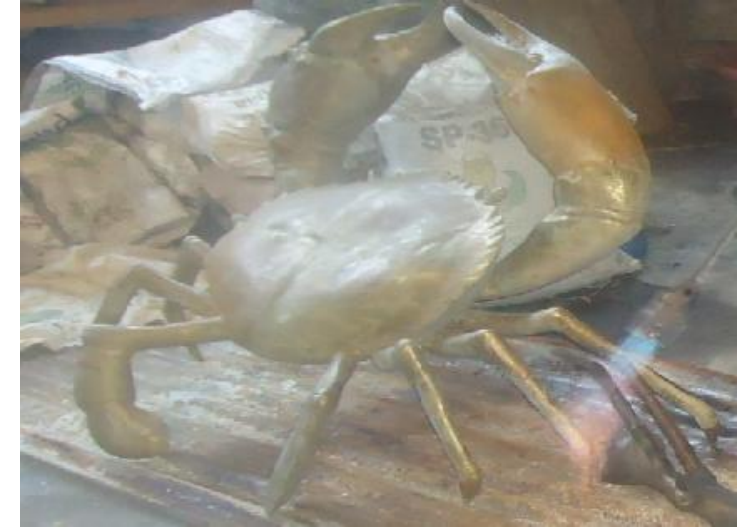

Figure 7. New Products SME "Whisnu”

Based on the identification of problems, especially in the areas of production management, there are problems of shortage of equipment for producing both the partner-1 "Whisnu" and partner-2 "Java Fiber". Equipment for the finishing process is still less like a machine polishing and grinding. Finishing equipment limitations cause yet refined product areas and uneven surface. In connection with keterbatas finishing equipment, then in the implementation of IbPE in this first year, diadalan finishing equipment such as engine with the power of the motor armature $6 \mathrm{pk}$. With the replacement of the polishing machine pengerjaaan finishing products faster. Thus the partners' products can increase quality and customer complaints for this can be overcome.

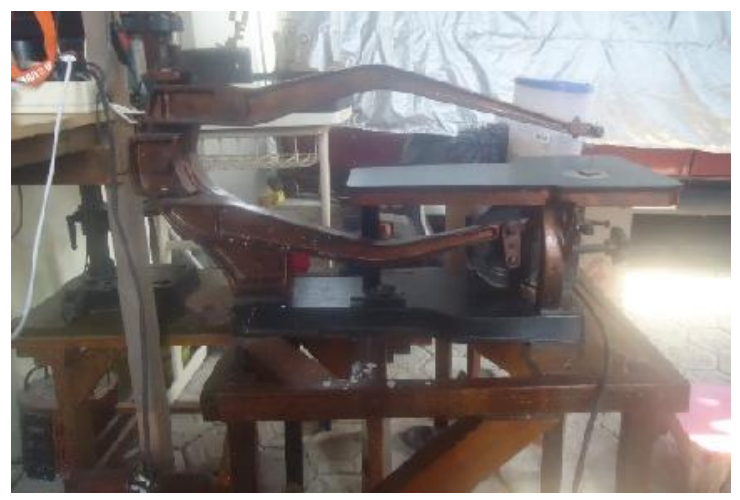

Figure 8. Several Additions Equipment for partners

\subsection{Conclusions}

Based on the activities that have been carried out, the conclusion can be formulated as follows:

1) SMEs can increase revenue by an average increase in revenue of $10 \%$.

2) SMEs do not have the skilled human resources on product design.

3) SMEs can prepare financial statements, although it is simple;

4) SMEs have a standard of quality assurance in the form of simple;

5) SMEs can improve product quality and speed up the production process;

6) The filing of copyright products are still in the process of each of the partners, one product.

7) SME "Java Fiber" has participated in the exhibition, both national and local;

8) SMEs can increase product variety with SME "Java Fiber" produces 4 new products and SME "Whisnu", 3 new products.

9) The additional equipment to support the production and finishing process has been undertaken.

10) Structuring showroom for each of the partners carried out well.

\subsection{Impacts and Benefits of Activities}

Implementation of PPM has an impact and benefits as follows:

1) SMEs have increased revenue by an average increase of $10 \%$ to the export market;

2) Some new export markets began to emerge that China's SMEs "Java Fiber" and South Korea's SMEs "Whisnu" 


\section{Acknowledgement}

In this occasion we would like to thank the Director of Research and Community Services, the Ministry of Research and Higher Education that has provided funding so that activities can proceed smoothly.

\section{References}

[1] J. Sriyana, "Strategi Pengembangan Usaha Keci dan Menengah (UKM): Studi Kasus di Kabupaten Bantul", dipresentasikan dalam Simposium Nasional 2010: Menuju Purworejo Dinamis dan Kreatif, Purworejo, 2010.

[2] Sudaryanto dan A. Hanim 2002, "Evaluasi kesiapan UKM Menyongsong Pasar Bebas Asean (AFTA) : Analisis Perspektif dan Tinjauan Teoritis", Jurnal Ekonomi Akuntansi dan Manajemen 1. 2 (2002): 30-37. 